\title{
EBF1 wt Allele
}

National Cancer Institute

\section{Source}

National Cancer Institute. EBF1 wt Allele. NCI Thesaurus. Code C80024.

Human EBF1 wild-type allele is located in the vicinity of 5q34 and is approximately $401 \mathrm{~kb}$ in length. This allele, which encodes transcription factor COE1 protein, is involved in the modulation of transcription. Genetic variation may be associated with both the occurrence and relapse of acute lymphoblastic leukemia. 